\title{
PERBAIKAN KEKUATAN DAN DAKTILITAS KOLOM BETON BERTULANG YANG MENDAPAT BEBAN GEMPA MENGGUNAKAN GLASS FIBER REINFORCED POLYMER
}

\author{
Parmo \\ Agoes Soehardjono M.D. \\ Tavio
}

\begin{abstract}
Abstrak: Penelitian ini bertujuan untuk mengetahui penambahan kekuatan dan daktilitas kolom beton bertulang setelah diretrofit menggunakan glass fiber reinforced polymer (GFRP) dan mendapat beban gempa. Penelitian ini menggunakan benda uji dua buah kolom dengan tiga kali pengujian. Masing-masing ukuran kolom 350 x 350 x $1100 \mathrm{~mm}$ dengan $\mathrm{f}^{\prime} \mathrm{c}=20,34 \mathrm{MPa}$ dan fy $=549,94 \mathrm{MPa}$. Pengujian dilakukan dengan memberikan beban aksial konstan $748 \mathrm{kN}$ dan beban lateral siklik yang menggunakan metode displacemet control untuk mensimulasikan beban gempa. Hasil penelitian menunjukkan peningkatan kapasitas lateral pada kolom sebesar 43,96\%. Retrofit kolom dengan GFRP bersifat daktail yang ditunjukkan dengan meningkatnya daktilitas perpindahan sebesar 129,14\% dan daktilitas kurvatur sebesar 118,27\%.
\end{abstract}

Kata-kata Kunci: glass fiber reinforced polymer, kekuatan, daktilitas, kolom beton

\begin{abstract}
Repairing the Strength and Ductility of Reinforced Concrete Column That Got Earthquake using Glass Fiber Reinforced Polymer. This study aims to identify the additional strength and ductility of reinforced concrete columns after being retrofitted using glass fiber reinforced polymer (GFRP) and got the brunt of the earthquake. This study uses two objects tested columns, which are being tested for three times. Each column size is $350 \times 350 \times 1100 \mathrm{~mm}$ with $\mathrm{f}^{\prime} \mathrm{c}=20.34 \mathrm{MPa}$ and fy $=549.94$ $M P a$. The testing is performed by giving a constant axial load of $748 \mathrm{kN}$ and cyclic lateral load using control displacement method in order to simulate the brunt of earthquake. The results show an increase in lateral capacity of column by $43.96 \%$. Retrofitting the column with GFRP has a ductile property, which is shown by the increase of the displacement ductility by $129.14 \%$ and curvature ductility by $118.27 \%$.
\end{abstract}

Keywords: glass fiber reinforced polymer, strength, ductility, concrete column

$I^{\prime}$ ndonesia menempati zona tektonik yang sangat aktif karena tiga lempeng besar dunia dan sembilan lempeng kecil lain- nya saling bertemu di wilayah Indonesia dan membentuk jalur-jalur pertemuan lempeng yang kompleks. Keberadaan

Parmo adalah Mahasiswa Program Magister Teknik Sipil-Struktur FT Universitas Brawijaya Malang dan Tim Teknis Universitas Negeri Malang; Agoes Soehardjono M.D. adalah Guru Besar Teknik Sipil-Struktur FT Universitas Brawijaya Malang; dan Tavio adalah Dosen Teknik Sipil-Struktur FTSP Institut Teknologi Sepuluh Nopember. 
interaksi antarlempeng ini menempatkan wilayah Indonesia sebagai wilayah yang rawan terhadap gempa bumi. Tingginya aktivitas kegempaan ini dapat dilihat dari hasil pencatatan dalam rentang waktu 1897-2009 terdapat lebih dari 14.000 kejadian gempa dengan magnituda $\mathrm{M}>5,0$. Gempa bumi yang terjadi di Indonesia dan di dunia telah menyebabkan jutaan korban jiwa, keruntuhan dan kerusakan ribuan infrastruktur serta bangunan, dan dana trilyunan rupiah untuk rehabilitasi dan rekonstruksi (Tim Revisi Peta Gempa Indonesia, 2010). Untuk meminimalkan akibat yang ditimbulkan oleh gempa dapat berupa: (1) penyediaan peralatan keadaan darurat (emergency), (2) tempat tinggal atau bangunan yang tahan gempa, dan (3) prediksi terhadap gempa (Krisnamurti, 2009).

Hal yang tidak kalah penting akibat bencana alam gempa bumi adalah persoalan setelah terjadinya gempa. Teknik retrofit struktur bangunan dengan cara GFRP jacketing dapat digunakan sebagai alternatif solusi untuk mengembalikan kekuatan dan daktilitas struktur akibat gempa. Representasi yang tepat untuk menggambarkan beban gempa yang terjadi adalah beban siklik.

Kolom merupakan elemen struktur yang penting karena kegagalan kolom akan berakibat langsung terhadap komponen struktur lainnya. Kegagalan ini akan berakibat fatal baik dari segi ekonomis maupun dari segi kemanusiaan (korban jiwa), sehingga dalam suatu struktur keruntuhan kolom struktural merupakan hal yang sangat penting untuk ditinjau.

Komposit serat kaca adalah jenis serat yang relatif lebih murah dibanding serat karbon dan serat aramid. Serat kaca memiliki regangan yang lebih besar dibandingkan serat karbon, seperti yang ditunjukkan pada Gambar 1. Keuntungan lain serat kaca adalah relatif lebih murah dibanding serat lainnya, kekuatan tarik yang tinggi, ketahanan kimia yang tinggi, dan memiliki sifat isolasi sangat baik. Selain itu kolom perkuatan GFRP memiliki perilaku daktil meskipun serat yang digunakan adalah brittle (Nguyen, 2010).

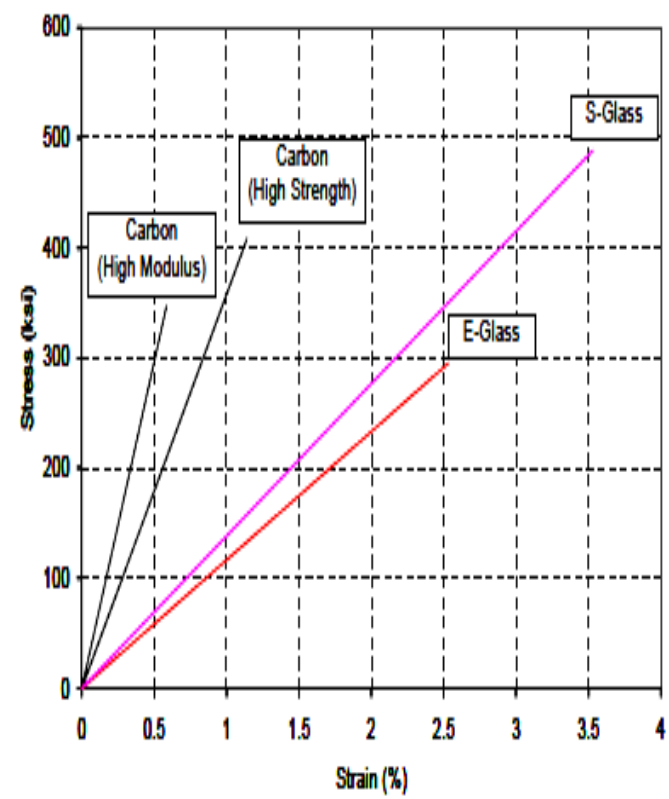

Gambar 1. Sifat Mekanis Serat Kaca dan Serat Karbon

Sudarsana dan Sutapa (2007), menyatakan bahwa hasil pengujian menunjukkan perkuatan kolom bulat beton bertulang dengan metode jacketing satu lapis GFRP mampu meningkatkan daya dukung aksial $11,86 \%$ sampai $15,25 \%$ dan daktilitas aksial sebesar $12,41 \%$ sampai dengan $47,14 \%$.

Dhinakaran, dkk. (2010), telah melakukan penelitian terhadap kolom yang diberi perkuatan GFRP dan menyatakan bahwa jika ditinjau dari aspek durabilitas kolom yang diperkuat dengan GFRP bersifat ductile dan jika ditinjau dari segi harga kolom yang diperkuat dengan GFRP lebih murah 6,60\% dibandingkan dengan perkuatan eksternal pelat baja setiap unit section-nya.

Penelitian oleh Elhassan dan Hurt 1995 (dalam Teng, dkk., 2007:213), contoh sukses dari penggunaan GFRP untuk retrofit hotel 7 lantai di Los Angeles aki- 
bat gempa bumi. Kolom-kolom bangunan hotel mengalami retak yang signifikan akibat gempa bumi Landers berkekuatan 7,5 skala Richter pada tanggal 28 Juni 1992 yang berpusat $175 \mathrm{~km}$ dari gedung. Retrofit kolom tersebut menggunakan GFRP jacketing setelah selesai beberapa minggu terjadilah gempa bumi Northridge tahun 1994 dan bangunan tidak mengalami kerusakan akibat gempa tersebut.

Hasil penelitian Memon dan Sheikh (2005), pada kolom beton bertulang persegi dengan ukuran 305 x 305 x $1473 \mathrm{~mm}$ dengan pondasi ukuran $508 \times 762 \times 813$ $\mathrm{mm}$, diberi beban aksial konstan dan beban lateral siklik diperoleh simpulan bahwa kolom beton bertulang persegi yang di retrofit dengan perkuatan eksternal GFRP wraps dan dilakukan uji terhadap beban aksial konstan dan beban siklik, yang menggambarkan beban gempa, menunjukkan perilaku peningkatan daktilitas dibandingkan kolom tanpa retrofit. Perilaku tahan gempa ditunjukkan adanya peningkatan daktilitas dan penyerapan energi.

Kapasitas beban aksial nominal teoritis dari kolom non slender perkuatan FRP dengan pengekangan tied (Persamaan 1). Pada struktur kolom, beban aksial merupakan representatif dari berat sendiri dan beban siklis merupakan beban luar yang terjadi berulang. Beban aksial dan siklis ini akan bekerja secara bersamaan pada struktur kolom pada saat terjadi gempa. Untuk memprediksi perilaku struktur beton di bawah pembebanan seismik, model tegangan-regangan beton di bawah beban siklik (loop histeresis) adalah hal yang penting untuk diamati (Watanabe, dkk., 2004) dan digambarkan seperti Gambar 2.

Daktilitas adalah kemampuan dari suatu struktur untuk tidak mengalami keruntuhan secara tiba-tiba (brittle) tetapi masih mampu berdeformasi cukup besar pada saat mencapai beban maksimum sebelum struktur tersebut mengalami keruntuhan (Park dan Paulay, 1975). Daktilitas dari suatu elemen biasanya diekspresikan sebagai rasio antara deformasi ultimit dan deformasi saat leleh pertama kali. Suatu struktur dikatakan daktail, apabila struktur menerima beban gempa dan struktur tersebut masih mampu tetap berdiri tanpa mengalami keruntuhan.

Faktor daktilitas (indeks daktilitas) berupa daktilitas curvature $\left(\mu_{\phi}\right)$ (Persamaan 2) dan daktilitas displacement $\left(\mu_{\Delta}\right)$

$$
P_{n(\text { maks })}=0,80\left[0,85 \psi_{f} f^{\prime}{ }_{c c}\left(A_{g}-A_{s t}\right)+f_{y} A_{s t}\right]
$$
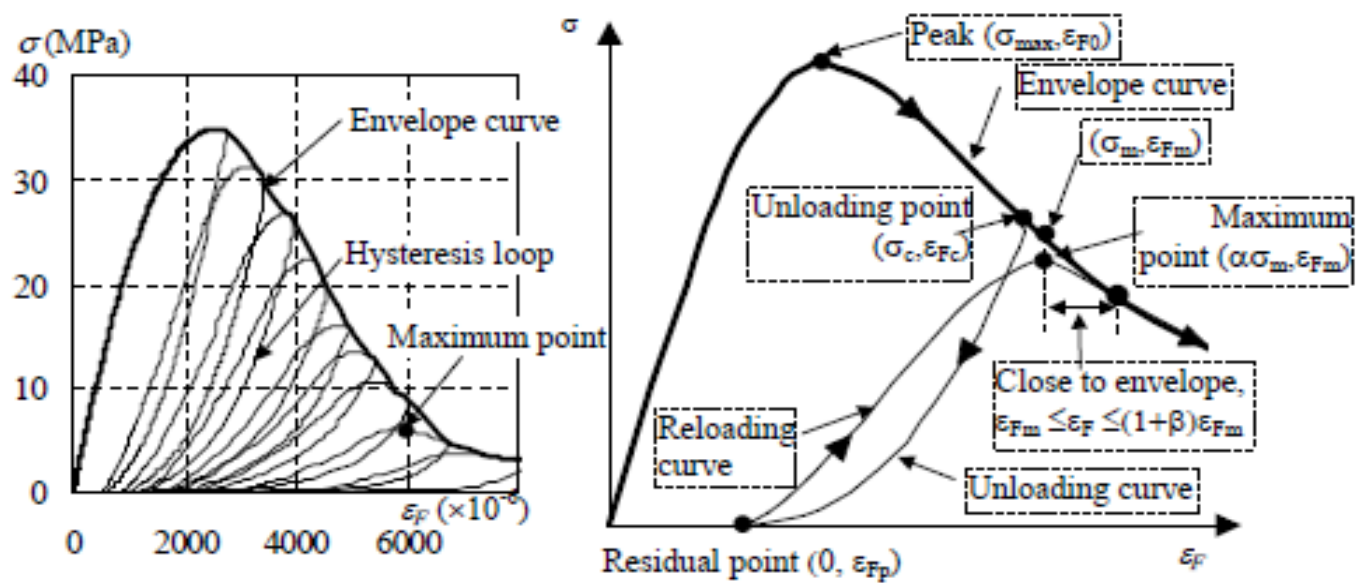

Gambar 2. Histerisis Loop 
(Persamaan 3, 4, dan 5). Selisih antara perpindahan ultimit dan perpindahan leleh adalah perpindahan plastis,

$$
\begin{aligned}
& \Delta_{p}=\Delta_{u}-\Delta_{y} \\
& \mu_{\phi}=\frac{\phi_{u}}{\phi_{y}} \\
& \mu_{\Delta}=\frac{\Delta_{u}}{\Delta_{y}} \\
& \delta=\frac{\Delta_{u}}{L} \\
& \mu_{\Delta}=\frac{\Delta_{u}}{\Delta_{y}}=1+\frac{\Delta_{p}}{\Delta_{y}} \\
& \Delta_{u}=\Delta_{y}+\Delta_{p}=\frac{{ }^{\phi} y^{L^{2}}}{3}+\left(\phi_{u}-\phi_{y}\right) l_{p} \\
& \left(L-0,5 l_{p}\right) \\
& \mu_{\Delta}=1+3\left(\mu_{\phi}-1\right) \frac{{ }^{l} p}{L}\left(1-0,5 \frac{{ }^{l} p}{L}\right)
\end{aligned}
$$

Persamaan (6) dan (7) menunjukkan bahwa ada hubungan linear antara daktilitas kelengkungan dan daktilitas perpindahan kolom. Di sini juga dapat diamati bahwa panjang sendi plastis $l_{p}$ dan ketinggian kolom $L$ merupakan dua faktor penting yang mempengaruhi hubungan ini.

Umumnya, struktur memerlukan retrofit dengan perkuatan eksternal dikarenakan oleh: (1) Terjadi perubahan fungsi bangunan atau bilamana elemen-elemen strukturnya dirancang sesuai tata cara yang lama dimana beban gempa nominalnya lebih rendah dari yang ditetapkan oleh tata cara saat ini. (2) Struktur tersebut sebelumnya hanya didesain terhadap beban gravitasi saja. Struktur tersebut menerima beban yang lebih besar akibat beban gempa sehingga struktur tersebut bisa tidak kuat yang mengakibatkan kerusakan atau bahkan kegagalan/keruntuhan. (3) Adanya retak mikro pada beton, yang mengakibatkan tulangan baja mengalami korosi karena pengaruh lingkungan seperti garam, bahan kimia, dan kelembaban. Sehingga struktur mengalami penurunanan kekuatan, kekakuan, service life serta kegagalan beton yang pada akhirnya dapat mengakibatkan kegagalan struktural. (4) Perubahan struktur akibat gempa yang ditandai dengan retak-retak mikro dan lendutan yang masih diijinkan dengan asumsi bahwa setelah dilakukan kajian teoritis struktur masih layak dilakukan retrofitting.

Penelitian ini bertujuan untuk mengetahui penambahan kekuatan dan daktilitas kolom beton bertulang persegi setelah di retrofit dengan menggunakan GFRP akibat beban gempa.

\section{METODE}

Benda uji berupa kolom beton bertulang persegi berjumlah 2 (dua) buah dengan 3 (tiga) kali pengujian aksial-siklik yaitu C-1 (original column/control column), C-1R (kolom yang diuji dan dihentikan pada drift rasio 2,20\%, mengalami retak dan sebagian tulangan longitudinal telah mengalami leleh sebagai representasi kolom yang mengalami kerusakan akibat gempa) dan C-1RG (kolom $\mathrm{C}-1 \mathrm{R}$ yang telah diperbaiki dengan cara retak-retak yang terjadi setelah diuji/diberi kerusakan dilakukan injeksi setelah itu dilakukan retrofit dengan perkuatan GFRP 1 lapis). Dimensi kolom 350 x $350 \mathrm{~mm}$, panjang $1100 \mathrm{~mm}$ dan diberi tulangan longitudinal baja 8D19 mm dengan tulangan sengkang baja jarak Ø10-200 mm, diperkuat dengan penjepit pelat baja untuk memodelkan tumpuan jepit seperti Gambar 3 dan 4.

Beton yang digunakan dalam penelitian ini adalah beton ready mix mutu f'c 20,34 MPa. Baja tulangan yang dipakai pada penelitian ini untuk tulangan longitudinal dipakai baja tulangan deform 


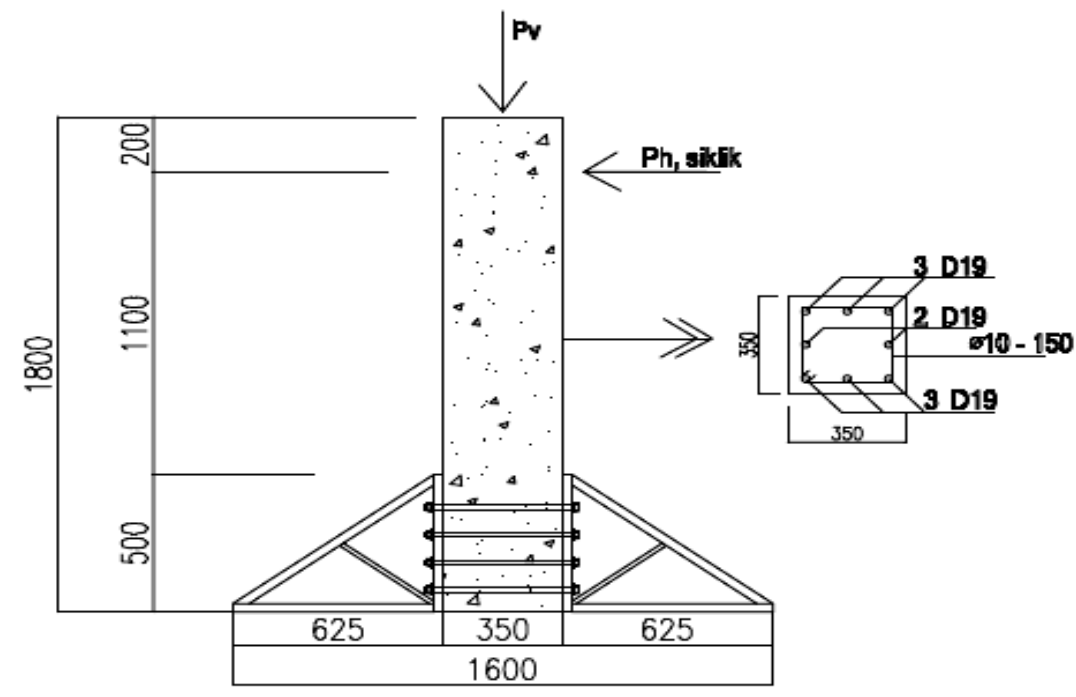

Gambar 3. Kolom Kontrol (C-1) dan Kolom yang Diberi Kerusakan (C-1R)

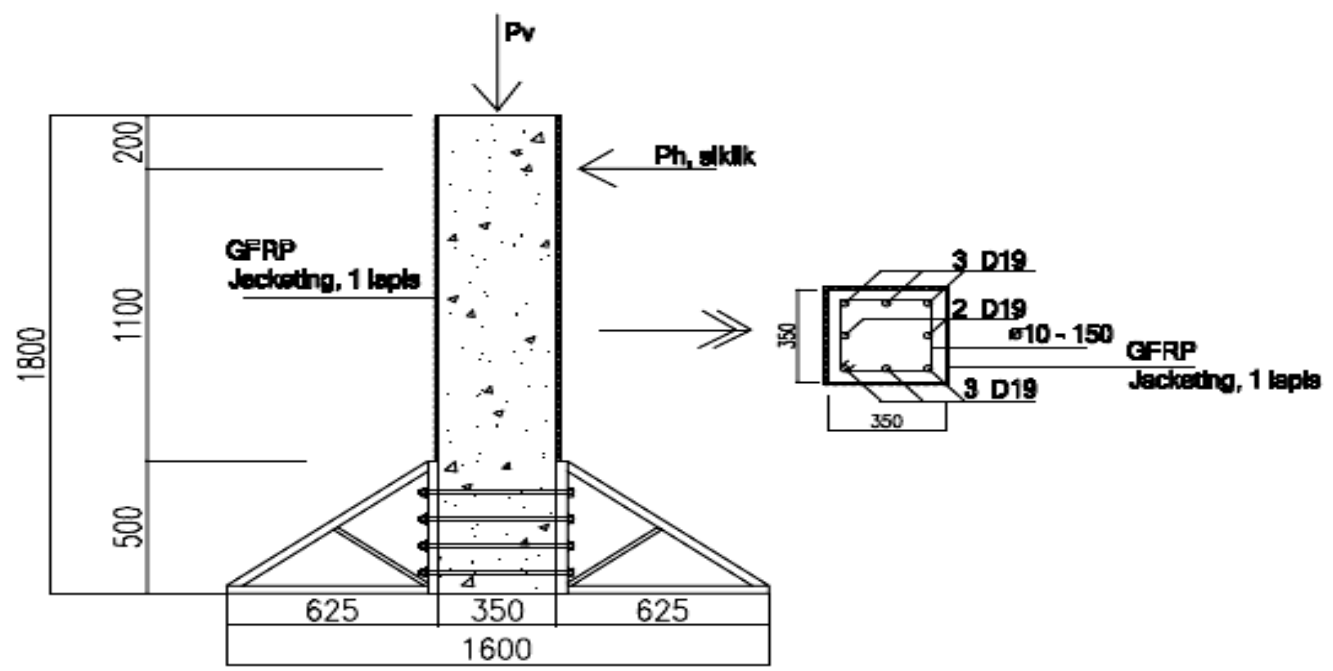

Gambar 4. Kolom Retrofit dengan Perkuatan GFRP 1 Lapis (C-1RG)

dengan diameter $19 \mathrm{~mm}$ sebanyak 8 buah. Sedangkan tulangan sengkang menggunakan baja polos diameter $10 \mathrm{~mm}$ jarak $200 \mathrm{~mm}$. Dari hasil uji tarik tulangan diperoleh nilai tegangan leleh rerata untuk tulangan pokok fy $=549,94 \mathrm{MPa}$ dan tegangan leleh rerata tulangan sengkang 386,52 MPa. Material GFRP digunakan dalam penelitian ini adalah produk Fyfe Co. LLC dengan merk dagang Tyfo ${ }^{\circledR}$ SEH-51A.
Pelaksanaan pengujian dilakukan dengan menempatkan benda uji kolom berdiri tegak pada 2 (dua) buah rangka baja (frame loading) yang diletakkan dengan cara mengunci pada balok tumpuan dengan pelat baja penjepit (pondasi) yang menggunakan mur-baut. Selanjutnya kepala kolom dihubungkan dengan load cell. Peralatan utama yang digunakan dalam pengujian adalah load cell, hydraulic jack, hydraulic actuator, pompa hidrolik, 
strainmeter, dan dial gauge. Setting-up pengujian ditunjukkan pada Gambar 5.

Besar beban aksial yang bekerja adalah konstan sebesar $748 \mathrm{kN}$ dan dilakukan variasi untuk beban siklik dengan metode displacement control. Pola pembebanan mengacu pada ACI 374.1-05 (Gambar 6) dengan rasio drift $\Delta / \mathrm{L}\left(\mathrm{x} 10^{2}\right)$ : 0,$20 ; 0,25 ; 0,35 ; 0,50 ; 0,75 ; 1,00 ; 1,40$; 1,$75 ; 2,20 ; 2,75 ;$ dan 3,50 .

\section{HASIL}

Hasil yang diperoleh antara kolom original/kontrol akan dibandingkan dengan kolom retrofit 1 lapis GFRP. Analisis teoritis diperoleh dari perhitungan diagram interaksi, sedangkan hasil pengujian siklik diperoleh data-data beban lateral $\left(P_{h}\right)$, lendutan $(\delta)$, regangan beton, regangan baja dan regangan GFRP.

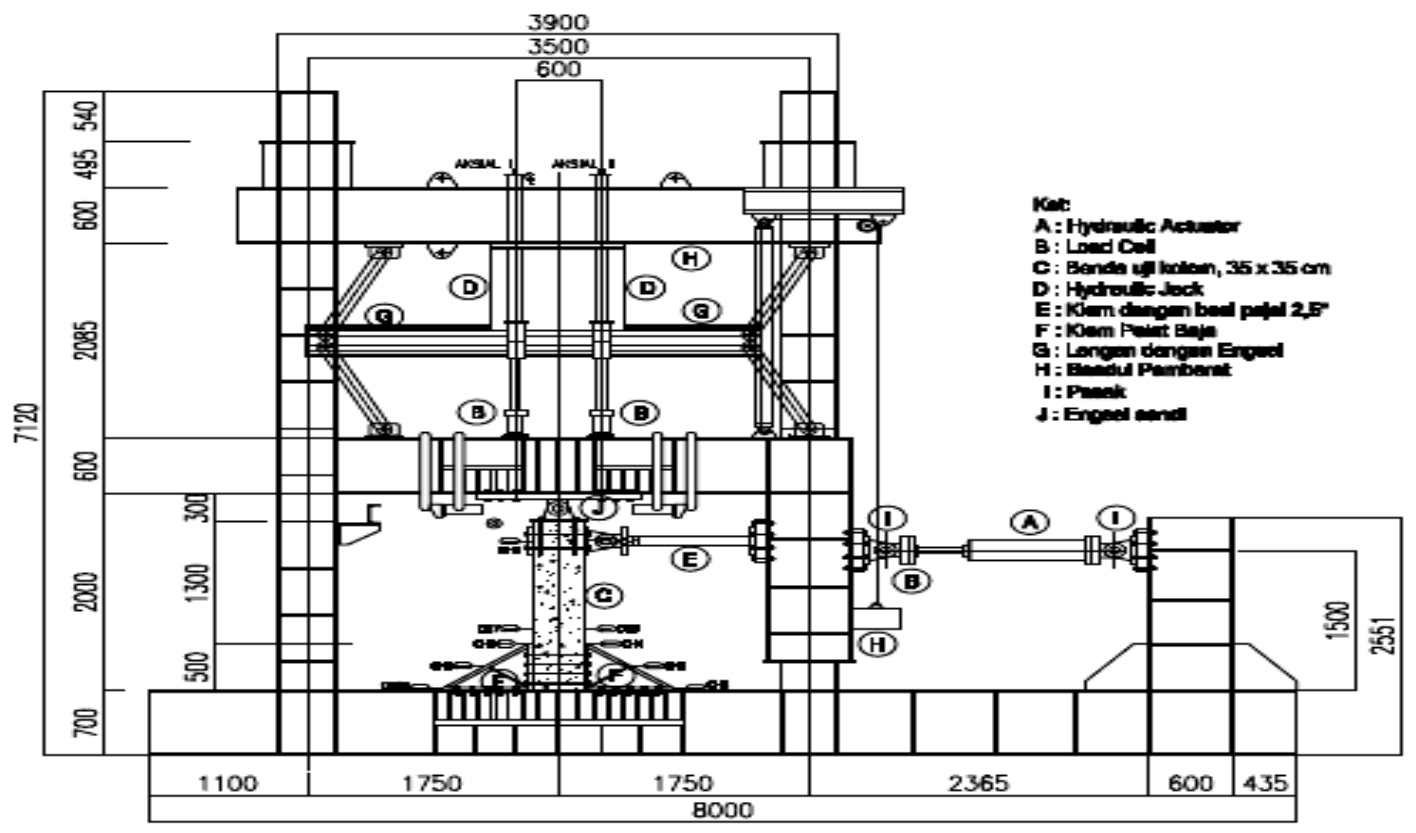

Gambar 5. Setting-up Pengujian Kolom

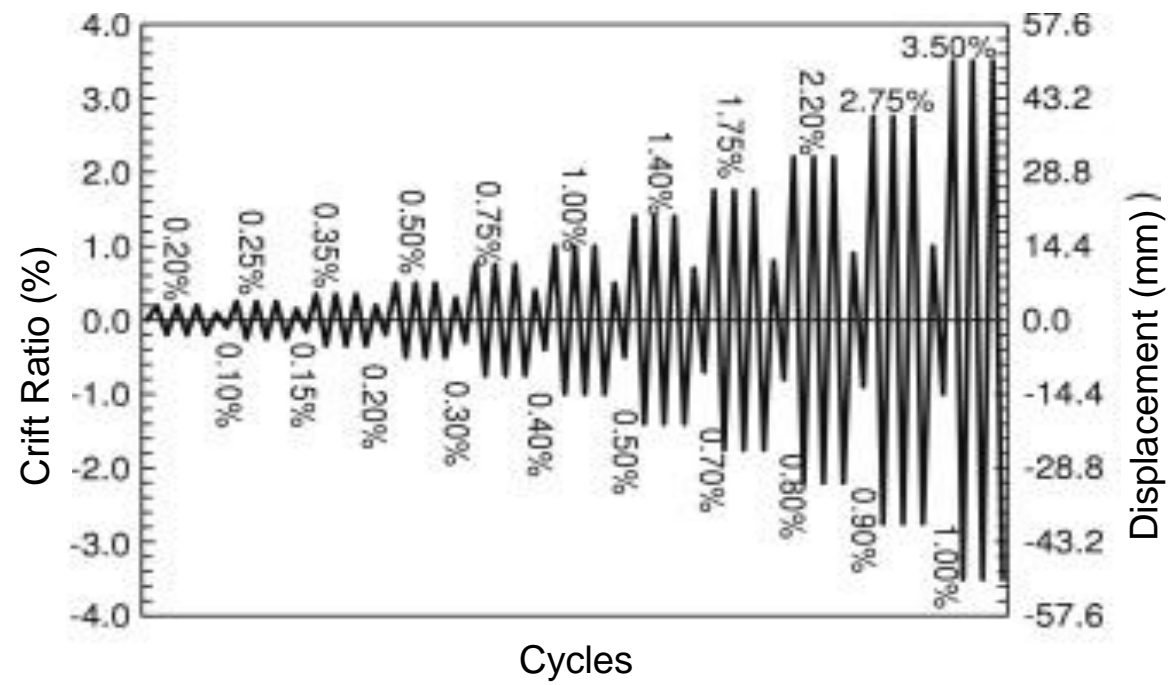

Gambar 6. Pola Pembebanan 
Peningkatan kekuatan kolom ditunjukkan dengan meningkatnya kapasitas momen, dengan naiknya kapasitas momen maka dapat diartikan beban lateral juga meningkat seperti yang ditunjukkan pada Gambar 7. Peningkatan kekuatan kolom ditunjukkan oleh meningkatnya kapasitas beban horizontal $\left(P_{h}\right)$ dan momen. Pada kolom original secara teoritis diperoleh $P_{h}$ sebesar $185,73 \mathrm{kN}$ sedangkan kolom retrofit GFRP diperoleh $P_{h}$ sebesar $225,54 \mathrm{kN}$. Sedangkan momen didapatkan nilai 202,45 kN untuk kolom original dan 202,45 kN untuk kolom retrofit GFRP. yang terjadi merupakan retak lentur yang ditandai dengan arah retak transversal menuju tinggi/lebar kolom. Pada ujung kepala kolom terjadi retak dan spalling beton, hal ini disebabkan karena perkuatan ujung kolom yang kurang besar. Retak di daerah sendi plastis dan spalling pada ujung kolom C-1R ditunjukkan pada Gambar 8. Pada benda uji C-1R tidak diperoleh $P_{\text {maks }}$ dikarenakan pembebanan dihentikan pada drift 2,20\% untuk keperluan retrofit kolom yang sama.

Pada kolom C-1RG retak awal terjadi pada beban $-360,10 \mathrm{kN}$ dan drift ke

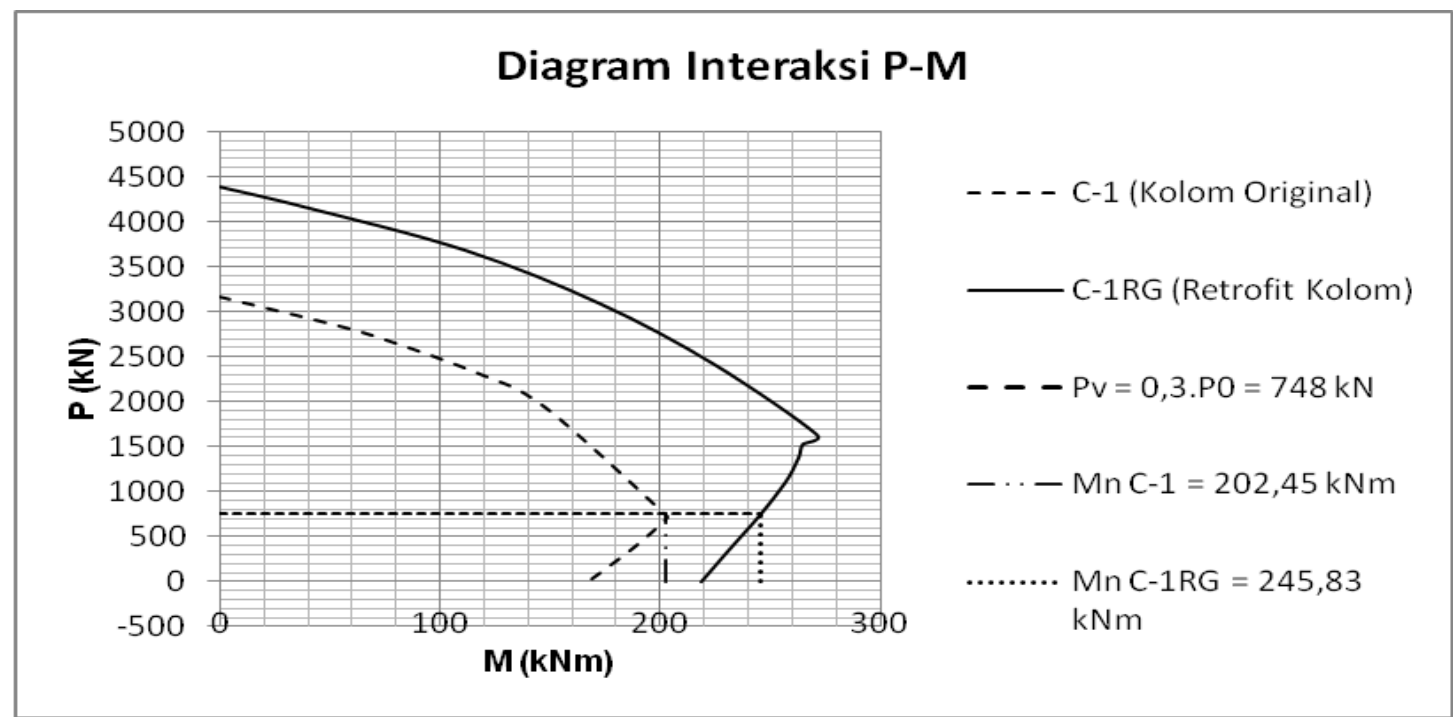

\section{Gambar 7. Diagaram Interaksi Benda Uji}

Pada kolom C-1 retak awal terjadi pada beban horizontal sebesar $-226,40 \mathrm{kN}$ di drift rasio $1,40 \%$. Spalling kolom terjadi pada saat beban mencapai $250,10 \mathrm{kN}$ drift $2,75 \%$ yang menyebabkan tulangan longitudinal terlihat dengan jelas. $P_{\text {maks }}$ terjadi pada beban horizontal $-288,00 \mathrm{kN}$ drift 3,50\%. Retak dan spalling pada kolom C-1 terjadi juga pada ujung kepala kolom, hal ini disebabkan karena kesalahan pada saat setting up pengujian beton yang tidak diberi perkuatan penjepit kolom pada bagian ujung. Pada kolom C-1R retak awal terjadi pada beban $-216,10 \mathrm{kN}$ dan drift ke $1,75 \%$. Retak
$3,50 \%$, retak yang terjadi pada kolom ditandai dengan debongding antara GFRP dan beton serta robeknya fiber jacketing. Spalling terjadi pada beban $-326,30 \mathrm{kN}$ didrift $5,50 \%$, pada saat terjadi spalling langsung diikuti keruntuhan kolom. $P_{\text {maks }}$ terjadi pada beban $-414,60 \mathrm{kN}$ drift 5,00\%. Sama dengan kedua kolom uji sebelumnya, retak yang terjadi merupakan retak lentur kolom. Kolom C-1RG merupakan retrofit dari kolom $\mathrm{C}-1 \mathrm{R}$ yang sebelumnya telah diuji dan dihentikan pada beban ke $210,50 \mathrm{kN}$ drift ke 2,20\%. Kolom C-1RG merupakan representasi dari kolom tengah gedung bertingkat (intermediate column). 


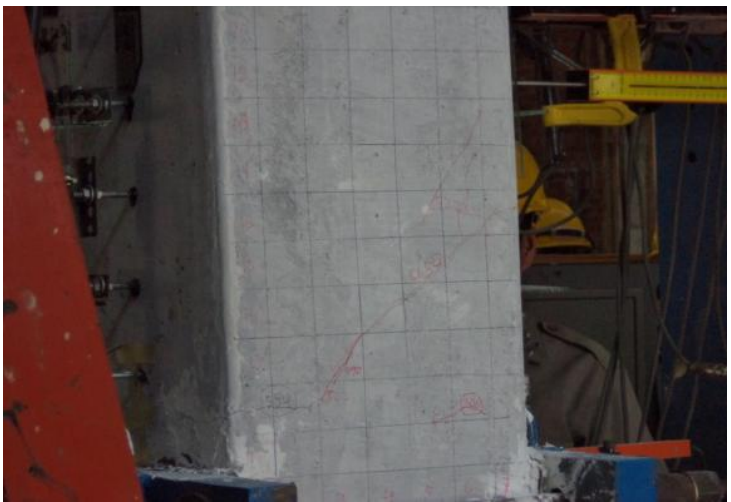

(a)

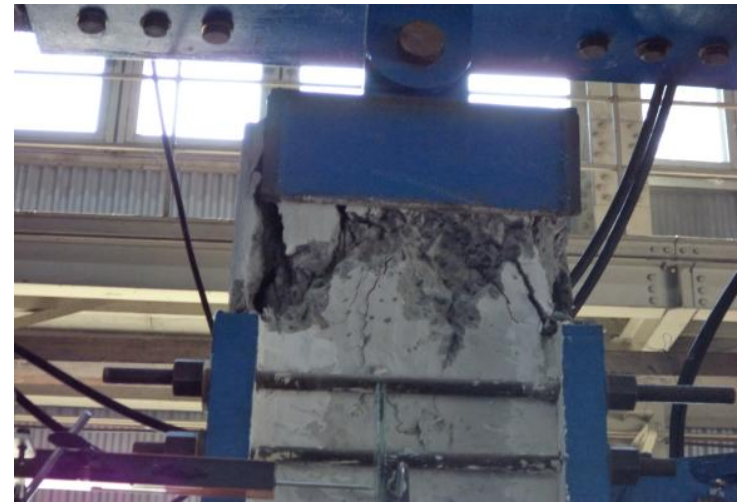

(b)

Gambar 8. Kolom C-1R: (a) Retak pada Daerah Sendi Plastis, (b) Retak dan Spalling pada Ujung Kepala Kolom

Penghentian uji pada drift ke 2,20\% mengacu pada ketentuan FEMA 368 dan dimungkinkan pada kondisi tersebut kolom masih dapat dilakukan perbaikan dan perkuatan untuk dikembalikan ke posisi awal perencanaan. Retak awal dan keruntuhan lentur kolom C-1RG ditunjukkan pada Gambar 9.

Tabel 1 menunjukkan beban saat terjadi retak awal, spalling dan beban maksimum. Beban pada saat terjadi retak awal, spalling dan beban maksimum kolom dihasilkan dari uji aksialsiklik.

Pengujian kolom C-1 dilakukan dengan pembebanan aksial konstan sebesar

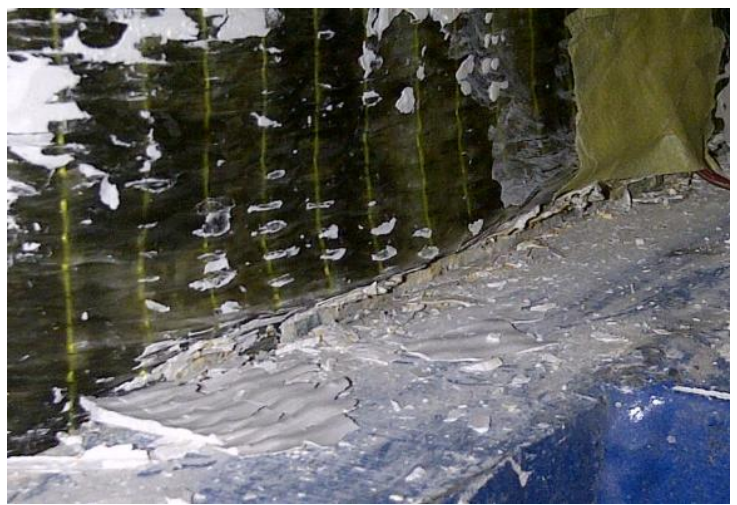

(a)
$748 \mathrm{kN}$ dan beban siklis dengan metode displacement control sehingga diperoleh nilai beban lateral. Hasil pengujian kolom C-1 diperoleh $\mathrm{Ph}_{\text {maks }}$ sebesar $-288,00 \mathrm{kN}$ pada drift rasio 3,50\%. Grafik hubungan P- $\Delta$ kolom C-1 ditunjukkan Gambar 10.

Pengujian kolom C-1R diberikan untuk mengetahui kerusakan pada kolom. Kolom C-1R mengalami kerusakan akibat gempa dengan visualisasi kolom telah mengalami retak pada daerah sendi plastis dan tulangan baja longitudinal sebagian mengalami leleh awal. Hasil pengujian kolom C-1R ditunjukkan Gambar 11.

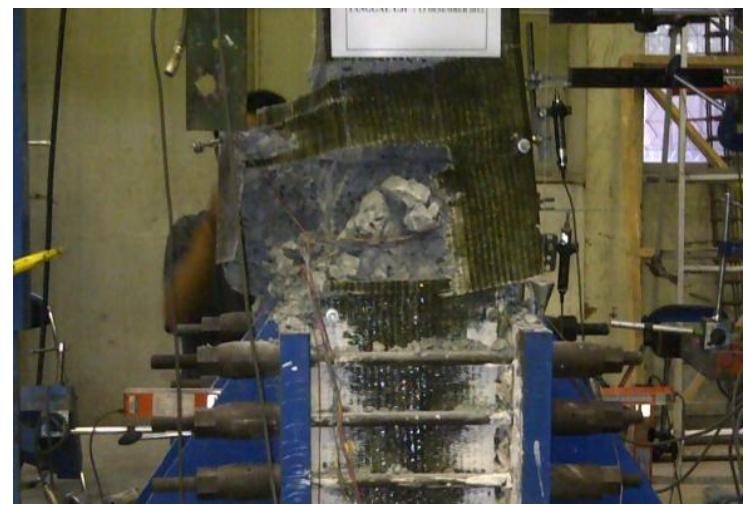

(b)

Gambar 9. Kolom C-1RG: (a) Retak pada Daerah Sendi Plastis, (b) Retak dan Spalling pada Ujung Kepala Kolom 
Tabel 1. Kolom Uji Mengalami Retak Awal, Spalling dan $\mathbf{P}_{\max }$

\begin{tabular}{lccc}
\hline Kolom Uji & Retak Awal/Drift (\%) & Spalling/Drift (\%) & Ph $_{\text {max }} /$ Drift (\%) \\
\hline C-1 & $-226,40 \mathrm{kN} / 1,40$ & $-250,10 \mathrm{kN} / 2,75$ & $-288,00 \mathrm{kN} / 3,50$ \\
$\mathrm{C}-1 \mathrm{R}$ & $-216,10 \mathrm{kN} / 1,75$ & - & - \\
$\mathrm{C}-1 \mathrm{RG}$ & $-360,10 \mathrm{kN} / 3,50$ & $326,30 \mathrm{kN} / 5,50$ & $-414,60 \mathrm{kN} / 5,00$ \\
\hline
\end{tabular}

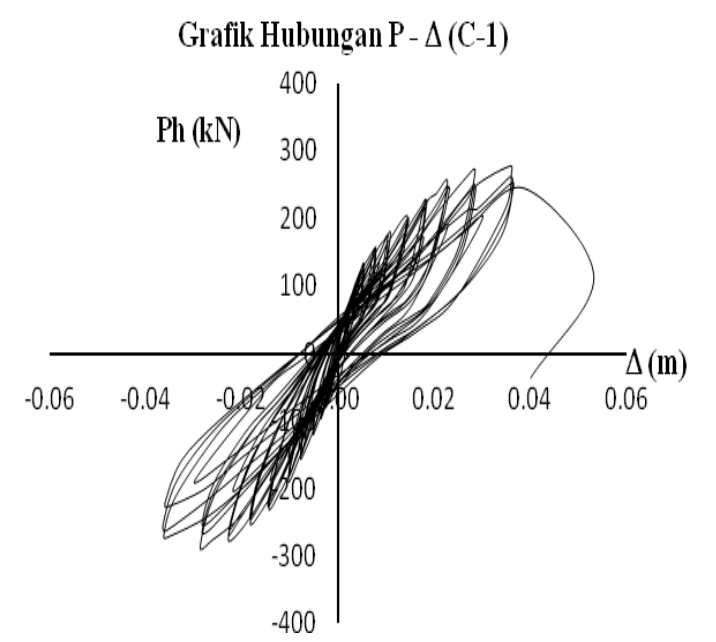

Gambar 10. Grafik Hubungan $P-\Delta$ Kolom C-1

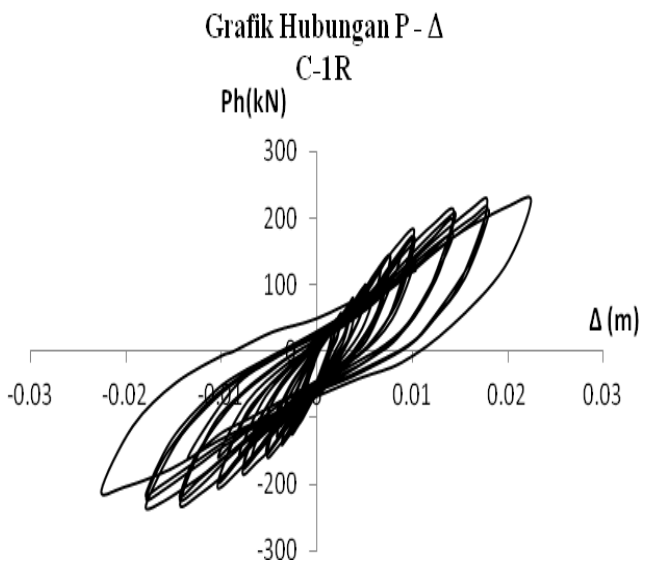

Gambar 11. Grafik Hubungan $P-\Delta$ Kolom C-1R

Selanjutnya kolom C-1R dilakukan perbaikan beton dengan cara melakukan grouting pada kepala kolom yang mengalami spalling dan melakukan injeksi pada daerah sendi plastis yang mengalami retak. Kolom yang telah dilakukan grouting dan injeksi dibiarkan kering \pm se- lama 7 hari selanjutnya dilapisi dengan perkuatan GFRP 1 lapis. Kolom C-1R yang telah diretrofit selanjutnya disebut C-1RG dan dilakukan pengujian aksialsiklik dengan metode yang sama seperti pada pengujian-pengujian sebelumnya. Dari hasil pengujian diperoleh data $\mathrm{Ph}_{\text {maks }}$ sebesar $-414,60 \mathrm{kN}$ pada drift rasio $5,00 \%$. Kolom mengalami keruntuhan pada daerah tarik setelah beban turun sebesar lebih kurang 30,00\%. Grafik hubungan P- $\Delta$ ditunjukkan pada Gambar 12.

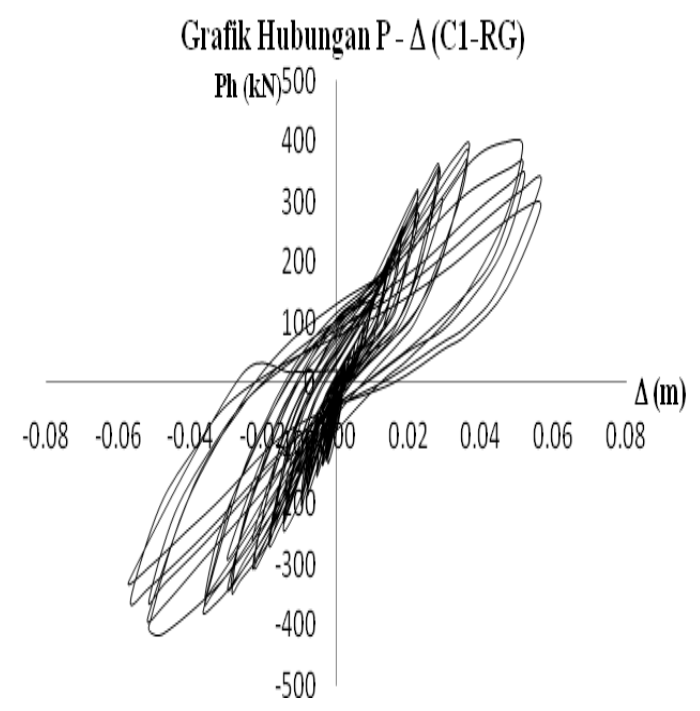

Gambar 12. Grafik Hubungan $P-\Delta$ Kolom C-1 RG

\section{PEMBAHASAN}

Dari analisis teoritis diagram interaksi kolom yang ditunjukkan Gambar 7 diperoleh $\mathrm{Ph}_{\text {maks }}$ kolom $\mathrm{C}-1$ sebesar $185,73 \mathrm{kN}$ dan $\mathrm{Ph}_{\text {maks }}$ kolom C-1RG sebesar 225,54, sehingga penambahan kapasitas beban lateral adalah sebesar 21,43\%. 
Sedangkan hasil pengujian eksperimen diperoleh $\mathrm{Ph}_{\text {maks }}$ kolom C-1 sebesar -288 $\mathrm{kN}$ dan $\mathrm{Ph}_{\text {maks }}$ kolom C-1RG sebesar $-414,60 \mathrm{kN}$, sehingga terjadi penambahan kapasitas lateral sebesar 43,96\%. Penambahan kekuatan pada penggunaan material GFRP untuk perkuatan sejalan dengan penelitian Sudarsana dan Sutapa (2007), hanya saja penelitian yang dilakukan oleh Sudarsana meliputi pembebanan aksial dan untuk mendapatkan penambahan kapasitas aksial. Penambahan $\mathrm{Ph}_{\text {maks }}$ pengujian kolom ditunjukkan Gambar 13. Untuk mengukur daktilitas digunakan 2 (dua) parameter yaitu daktilitas perpindahan $(\mu \Delta)$ dan daktilitas curvature $((\mu \varphi)$.

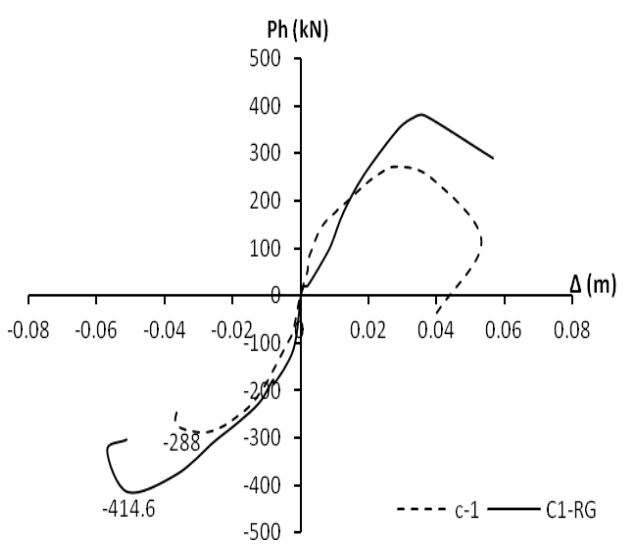

Gambar 13. Grafik Skeleton $P-\Delta$ Kolom C-1 dan C-1RG

Persamaan (8) dan (9) dipergunakan untuk menentukan nilai daktilitas. Nilainilai daktilitas $(\mu \Delta$ dan $\mu \varphi)$ ditunjukkan pada Tabel 2.

Grafik daktilitas perpindahan dan daktilitas kurvatur kolom C-1 dan C-1RG ditunjukkan Gambar 14, 15, 16, dan 17.

Tabel 2. Nilai $\mu \Delta$ dan $\mu \varphi$

\begin{tabular}{lcc}
\hline Kolom Uji & $\mu \Delta$ & $\mu \varphi$ \\
\hline C-1 & 4,53 & 3,94 \\
C-1RG & 10,38 & 8,60 \\
C-1R & \multicolumn{2}{c}{ Kolom C-1R tidak didapatkan } \\
& nilai daktilitas, karena dihenti- \\
& kan untuk keperluan retrofit \\
\hline
\end{tabular}

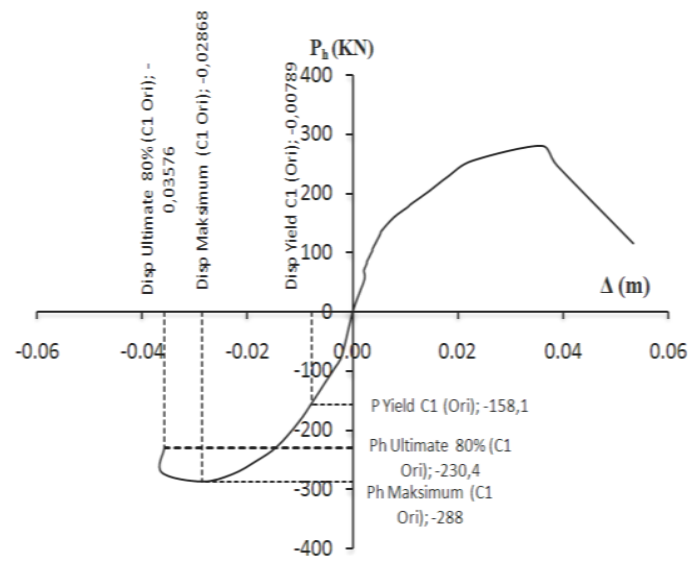

Gambar 14. Grafik Skeleton Hubungan Ph- $\Delta$ Kolom C-1

Dari Tabel 2 dapat diambil simpulan bahwa kolom C-1RG bersifat daktail dan jika dibandingkan dengan kolom C-1 nilai daktilitas kolom mengalami peningkatan daktilitas perpindahan (displacement ductility) sebesar 129,14\% dan meningkat sebesar 118,27\% untuk daktilitas curvature (curvature ductility). Perilaku ductile penggunaan material GFRP untuk perkuatan dan retrofit sejalan dengan penelitian sebelumnya yang dilakukan Dhinakaran, dkk. (2010), Elhassan dan Hurt (1995), serta Memon dan Sheikh (2005).

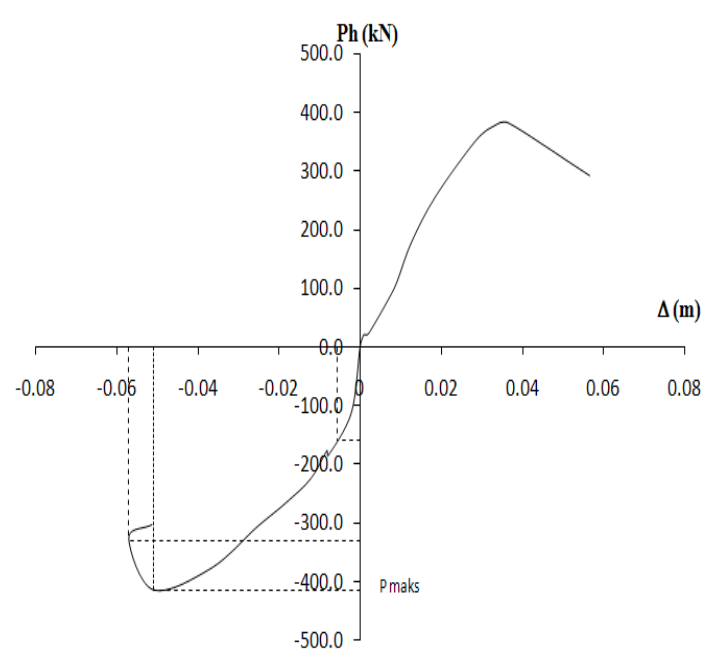

Gambar 15. Grafik Skeleton Hubungan Ph- $\Delta$ Kolom C-1RG 


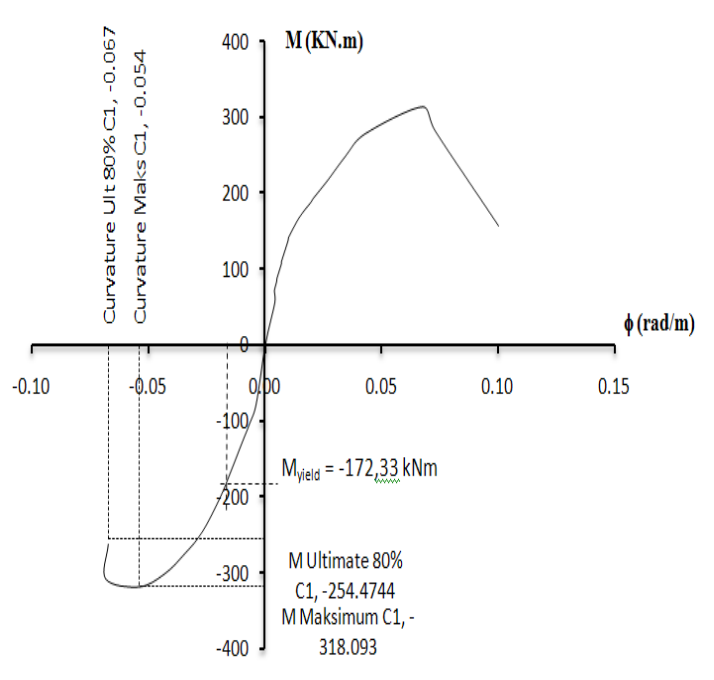

Gambar 16. Grafik Skeleton Hubungan M - $\phi$ Kolom C-1

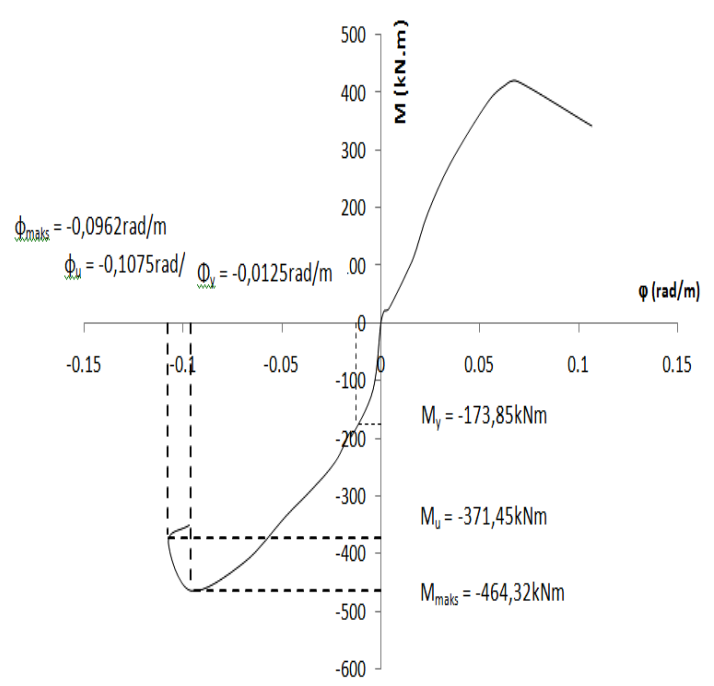

Gambar 17. Grafik Skeleton Hubungan M - $\phi$ Kolom C-1RG

\section{SIMPULAN DAN SARAN}

Berdasarkan hasil penelitian dapat disimpulan: (1) hasil analisis teoritis menunjukkan bahwa terjadi penambahan kapasitas lateral 21,43\% antara kolom C-1 denan C-1RG, (2) hasil eksperimental menunjukkan adanya penambahan kapasitas lateral $43,96 \%$ antara kolom C-1 dengan C-1RG, (3) kolom dengan retrofit GFRP bersifat daktil hal ini ditunjukkan dengan adanya penambahan daktilitas perpindahan $129,14 \%$ dan penambahan daktilitas kurvatur 118,27\% antara kolom C-1 dengan C-1RG setelah dilakukan uji eksperimental.

Saran yang diberikan adalah melakukan pengulangan benda uji agar hasil yang diperoleh bisa menggambarkan perilaku yang lebih valid dan perkuatan kepala kolom dengan pengekangan lebih agar tidak terjadi kerusakan.

\section{DAFTAR RUJUKAN}

Dhinakaran, G., Manoharan, K., \& Jeyasehar, C.A. 2010. Load Deformation Characteristics of GFRP Reinforced HPC Square Columns. Journal of Civil Engineering Research and Practice. 7(2):14.

Krisnamurti. 2009. Metode Analisis Struktur Akibat Beban Gempa. Jember: Jember University Press.

Memon, M.S. \& Sheikh, S.A. 2005. Seismic Resistance of Square Concrete Columns Retrofitted with Glass Fiber-Reinforced Polymer. ACI Structural Journal, 102(5):775.

Nguyen, K. 2010. Parametric Study of Glass Fiber Reinforced Polvmer Concrete Filled, under Lateral Loads. Center for Civil Engineering and Earthquake Research.

Park, R. \& Paulay, T. 1975. Reinforced Concrete Structures. Canada: John Wiley and Sons.

Sudarsana, I.K. \& Sutapa, A.A.G. 2007 Perkuatan Kolom Bulat Beton Bertulang dengan Lapis Glass Fiber Reinforced Polymer (GFRP). Jurnal Ilmiah Teknik Sipil, 11(1).

Teng, J.G., Huang, Y.L., Lam, L. \& Ye, L.P. 2010. Theoretical Model for Fiber Reinforced Polymer Confined 
Concrete. Journal of Structural Engineering (C) ASCE, 11(2):201-210.

Tim Revisi Peta Gempa Indonesia. 2010. Ringkasan Hasil Studi Tim Revisi Peta Gempa Indonesia 2010. Makalah Disajikan dalam Workshop Paparan dan tinjauan Teknis Peta Bahaya Gempa Indonesia Terbaru 2010. Bandung, 19 Juli.
Watanabe, K., Niwa, J., Yokota, H. \& Iwanami, M. 2004. Stress-strain relationship for the localized compressive failure zone of concrete under cyclic loading. First International Conference on Urban Earthquake Engineering. Yokohama Japan. 